\title{
The Strategic Role of Office of Institutional Research in
}

\section{University Organizational Development}

\author{
Jafar Toroghi \\ PhD candidate of Development Planning in Higher Education \\ Educational Sciences Department, , Shahid Beheshti University
}

Tehran 1983963113, Iran

Mahbubeh Arefi

Professor of Educational Sciences Department, Shahid Beheshti University

Tehran 1983963113, Iran

Hadi Marjaee

Assistant Professor of Planning Research of Higher Education Institute, Tehran

Received: March 18, 2016 Accepted: April 24, 2016 Published: May 22, 2016

doi:10.5296/ijhrs.v6i2.9179 URL: http://dx.doi.org/10.5296/ijhrs.v6i2.9179

\begin{abstract}
University organizational development is a strategic effort for continuous and organized university performance, which can provide an ability to internally and environmentally meet the requirements in the academic settings. It needs some measures such as domestic capacities and competences in university, as well as collecting and analyzing the required information to support the decision making of university management, which are defined as the responsibilities of Office of Institutional Research (OIR). The present research aims to determine the strategic role of OIR in university organizational development, investigating its features and dimensions in the selected universities. The findings highlight the most important strategies of OIR as follow: 1.collection, analysis, and publication of information, 2.studying on the process, planning, performance, resources, and effectiveness of decision making units in universities, 3.supporting the decision making of university management in planning and policy making, and improving the quality. The results of the current research depict a conceptual pattern involving the strategic elements of institutional research.
\end{abstract}

Keywords: Institutional research, Organizational development, Academic management, Decision making 


\section{Introduction}

In the age of globalization, information revolution, knowledge production and complicated conditions, surround higher education and universities. Therefore, universities inevitably need to conform to the complicated and flexible changes so efficiently that they would enable themselves to be modified and developed. This is inevitably achieved through research-based decision making. In this regard, OIR unit has been established for more than a half century in most high-ranked universities across the world with purpose of organizational development and carrying out several studies and research to provide the required information for university management to make effective decisions. This office is also involved in pathology, problem-solving, and making sure about optimal performance of different university sectors.

In this connection, there is an important question; what conditions and features should an OIR have to make organizational development in universities? Can a conceptual pattern for its effort for organizational development be extracted and presented?

In order to investigate the answers of the questions, some expert were asked to delineate the goals and responsibilities in the selected universities. Due to improving the undesirable status of organizational development and institutional research within conceptual, structural, and performative frameworks, it seems that, the results of this paper can provide a general guideline and key useful clues to commence and continue the activity of OIR in universities.

\section{Theoretical Foundations}

\subsection{Strategic Requirements of Institutional Research}

Identifying the academic policies and status, as well as empowering the universities to be warmly welcomed in in the future are fundamentally academic challenges in the organizational development planning (Torkzadeh, 2009,). Therefore, the efforts made to change and develop the universities should fit the situation. This would be continuously fulfilled though OIR. In this regard, by globalization, development and competition, universities across the world have faced many challenges (Taylor, et al., 2013). In this situation, official and organizational researchers in universities and higher education can play a significant role in scrutinizing these challenges as well as warning the university leaders about their effects in universities and higher education. The future challenges of higher education institutes will be considered as global. How to meet the increasing and diverse social needs (with less general sources) and increasing the need to answer requires emphasis on IR, which has the basic role in a computational and global environment. Then, the need for them as a well- developed collection of general and specialized skills is more necessary than before. (Fincher, 2008)

Webber has taken institutional research as organizational intelligence or a vocational expertise enjoying ample facilities and resources for the academic policies (volkwein, 2008,). Moreover, Saupe (2008) considers IR as research activities are providing a collection of information to support policy making, planning and decision making process. Wilson (2010) believes that efficiently and effectively academic decisions should be made based on the 
research-based efforts, as well as accurate, up-to- date, and efficient information. Presenting required information, OIR helps the decision making process. Regarding the future academic development, it seems that establishing offices of institutional research in the Iranian universities will result in promoting standards of common information. Accordingly, it can be concluded that institutional research can influence the social reassurance. These efforts will be effective in meeting the expectations made after high school and in higher education. From the 80th onward, the majority of American universities have utilized OIR to carry out their responsibilities and principal missions, so that universities can be adjusted with variable environment and shape the future (Olson, 2000).

Efficient use of information leads to improvement of OIR mechanism. Therefore, it should be emphasized that designing the appropriate information system (IS), including information technology and data process is the primary step in having a well-developed OIR(Esmall, 2004). The IS process the data and change them to user's required information (Lim\& Kim, 2004). However, Information systems have not yet been developed to think, plan, and react to how the changes are made (Hatua, 2010). Therefore, information technology is software or hardware which quickly stores, manipulates, and transfers the information, and consists of computerized links, electronic posts, video conference, and computerized data bases (Edwards, 2003). Some researchers consider information communication and technology (ICT) as a tool to create a relation and facilitate the exchange because of the capabilities of changing and storing the experiences in data bases and its easy promotion among users (Clark, 2006). Furthermore, the capability of participation and knowledge transfer enables the organization to better, quickly, ad cheaply make a decision (Glier, 2003). Parker (1988), Mason \& Swanson (1981) and Ward (1995) have classified information systems in particular ways based on different approaches, the main of which are: Transaction Processing System (TPS), Management Information System (MIS), Decision Support System (DSS), Expert System (ES), Executive Information System (EIS), and Group Decision Support System (GDSS).

The managers should view decision making as the second element of strategic requirements involved in the institutional research. They should consciously, correctly, and punctually make decision based on the variable situations of environment as flourishing academic capacities and competencies which are associated with situation (Atwell, 1996; Edwards, 1997; Dhamond, 2002). Decision making is a collection of activities and dynamic factors triggered through identifying a motive for activity while being accomplished by a particular commitment (Chamar, 2003). Lawden (2001) considers decision making process as four levels: 1.awarness, 2.design, 3.selection, 4. Apply. Levels of decision making in university management should be based on accurate, up-to-date, and efficient information. Therefore, OIR supports academic management decision making through presenting required information.

\subsection{Expertly categorization of OIR features}

Strategically speaking, this part is devoted to investigation of features and dimensions of IR. The experts' views are formulated in table 1: 
Table 1. IR features from the expert's viewpoints

\begin{tabular}{|c|c|c|}
\hline Author & Year & IR Features \\
\hline $\begin{array}{l}\text { Olson, } \\
\text { Bidokhti }\end{array}$ & 2000 & $\begin{array}{l}\text { University unit is a source of data production, linking data to } \\
\text { internal and external fields of university. OIR changes the data to } \\
\text { the meaningful information for planning and strategic } \\
\text { management of university, so that universities can be adjusted to } \\
\text { the variable environment and shape the future. }\end{array}$ \\
\hline $\begin{array}{l}\text { Volkwein, } \\
\text { Bidokhti }\end{array}$ & 2008 & $\begin{array}{l}\text { IR involves research activities which provide a collection of } \\
\text { information to support policy making, planning, and decision } \\
\text { making process. }\end{array}$ \\
\hline $\begin{array}{l}\text { Terenzini, } \\
\text { Patrick, } \\
\text { Bidokhti }\end{array}$ & 2013 & $\begin{array}{l}\text { IR as organizational intelligence is defined in three categories: } \\
\text { analytical intelligence, topic intelligence, and field intelligence. } \\
\text { Analytical intelligence: analysis counts as key responsibility of } \\
\text { IR } \\
\text { Topic intelligence: a professional institutional researcher should } \\
\text { have, at least, the minimum knowledge in the field of researcher } \\
\text { literature in operational area. } \\
\text { Field intelligence: field intelligence should pass across the } \\
\text { university borders (radical knowledge governed over culture, } \\
\text { value, and traditions of the institute), which leads to the } \\
\text { successful performance of universities. }\end{array}$ \\
\hline $\begin{array}{l}\text { Entezari, } \\
\text { Bidokhti }\end{array}$ & 2004 & $\begin{array}{l}\text { IR is the link between university and industry, and also improver } \\
\text { of knowledge productivity in universities. }\end{array}$ \\
\hline Branda & 1989 & $\begin{array}{l}\text { OIR operates to collect information support. These activities are } \\
\text { carried out by researchers, providing a scale to assess the } \\
\text { efficiency of university units. }\end{array}$ \\
\hline Midagh et al. & 1994 & $\begin{array}{l}\text { Institutional research is defined as the "whole activities related to } \\
\text { description of a full spectrum of performance (education, } \\
\text { administrative, and support) carried out in a university or faculty. } \\
\text { Activities of OIR include collecting information and analytical } \\
\text { strategies in support of decision making in the institute } \\
\text { (Middaugh et al., 1994). The researchers in this office should } \\
\text { have the constant assessment of students' learning, report the }\end{array}$ \\
\hline
\end{tabular}




\begin{tabular}{|c|c|c|}
\hline & & $\begin{array}{l}\text { findings, and make use of the results to improve the current } \\
\text { planning. Effective institutional research supports the strategic } \\
\text { planning. Without such support, effective management in higher } \\
\text { education is impossible. }\end{array}$ \\
\hline Taylor & 1979 & $\begin{array}{l}\text { The essential role of IR is to improve the understanding, } \\
\text { planning, and using of higher education institute. This role is } \\
\text { undertaken through personal studies, collecting, analyzing, and } \\
\text { presenting common ordinary reports and studying about urgent } \\
\text { problems and issues. }\end{array}$ \\
\hline Saupe & 1981 & $\begin{array}{l}\text { It emphasizes practical aspects of institutional research, that is, } \\
\text { support of institutional management by presenting information } \\
\text { usable in institutional planning, policy codification, and decision } \\
\text { making. }\end{array}$ \\
\hline $\begin{array}{l}\text { Altbach and } \\
\text { Kelly }\end{array}$ & 1985 & $\begin{array}{l}\text { The research carried out in a higher education institute with } \\
\text { purpose of collecting and analyzing data related to plans and } \\
\text { activities of institute. }\end{array}$ \\
\hline Sheehan & 1980 & $\begin{array}{l}\text { It investigates the research and analysis of operation, } \\
\text { environment, and process of higher education institutes with the } \\
\text { aim of providing information in decision making in higher } \\
\text { education. }\end{array}$ \\
\hline Maassen & 1986 & $\begin{array}{l}\text { Institutional research consists of several essential supportive } \\
\text { activities. These activities are as follow: } \\
\text {-Data collection based on organizational performance } \\
\text {-Data collection based on organizational environment } \\
\text {-Analysis and interpretation of collected data } \\
\text {-Changing data results into the information to support the } \\
\text { decision in planning and management } \\
\text {-Monitoring educational quality in institutional plans }\end{array}$ \\
\hline $\begin{array}{l}\text { Webber .Karen } \\
\text { L, }\end{array}$ & 2012 & $\begin{array}{l}\text { OIR activities: } \\
\text { 1.Data collection } \\
\text { 2.Plannig, measurement and assessment based on combination of } \\
\text { information related to the theory, being aware of university } \\
\text { priorities and techniques of effective communication }\end{array}$ \\
\hline
\end{tabular}




\begin{tabular}{|l|l|l|}
\hline & & $\begin{array}{l}\text { 3. Obtaining support from university colleagues with aim of } \\
\text { collaborative and team work with IR, which is important as a } \\
\text { supportive actin for decision making }\end{array}$ \\
\hline Fincher & 1979 & $\begin{array}{l}\text { OIR demands individual and professional qualifications, } \\
\text { organizational understandings and understanding different } \\
\text { problems. To achieve these elements, organizational intelligence } \\
\text { is required. }\end{array}$ \\
\hline
\end{tabular}

The Office of Institutional Research organizes different quantitative analysis to goal and evaluates academic programs and administrative processes. The office collects, manages and organizes data to support the analytic and reporting needs.in table 2 we categorize some features of the best office of institutional research in the world.

Table 2. The features of Office of IR

\begin{tabular}{|l|l|}
\hline $\begin{array}{l}\text { Name of } \\
\text { University }\end{array}$ & OIR Features \\
\hline $\begin{array}{l}\text { Texas } \\
\text { University } \\
\text { organize, and transform data from multiple sources to produce predictive } \\
\text { analytics and descriptive statistics aligned with initiatives of the Office of the } \\
\text { Executive Vice President and Provost. Key functions of the Research Team } \\
\text { include: data collection, creating datasets from multiple and discordant } \\
\text { sources, conducting statistical analyses, interpreting results, generating } \\
\text { reports, and presenting to technical and non-technical audiences. The } \\
\text { Research Team provides information and analysis to support data-informed } \\
\text { decisions, institutional management, planning, and operations in the areas of } \\
\text { undergraduate students, graduate students, and faculty }\end{array}$ \\
\hline $\begin{array}{l}\text { The University } \\
\text { of Iowa }\end{array}$ & $\begin{array}{l}\text { The collection, analysis, interpretation, and dissemination of accurate and } \\
\text { timely information on all aspects of the university's activities in support of } \\
\text { institutional planning, decision-making and reporting. }\end{array}$ \\
\hline $\begin{array}{l}\text { California } \\
\text { institute } \\
\text { technology }\end{array}$ & $\begin{array}{l}\text { Collection, management, integration and analysis of data to inform } \\
\text { decision-making and resource allocation } \\
\text { Support of the campus mission and strategic initiatives. }\end{array}$ \\
\hline
\end{tabular}




\begin{tabular}{|c|c|}
\hline $\begin{array}{l}\text { Georgia } \\
\text { Institute of } \\
\text { Technology }\end{array}$ & $\begin{array}{l}\text { Develop and maintain comprehensive data and information systems required } \\
\text { for institutional study, management, and planning. These systems link data } \\
\text { across administrative lines and provide focused institutional data and } \\
\text { information necessary for concentrated analysis of issues significant to the } \\
\text { institution. Provide in-depth, substantive analysis of selected topics upon } \\
\text { request, with data and reports as appropriate in order to assist with the } \\
\text { translation of data into usable information. Provide data and other support for } \\
\text { the University's planning process and associated review, evaluation, and } \\
\text { assessment activities. }\end{array}$ \\
\hline $\begin{array}{l}\text { University of } \\
\text { Florida }\end{array}$ & $\begin{array}{l}\text { Responding to state and federal reporting requirements, eliminating } \\
\text { source-data discrepancies and developing procedures and programs. } \\
\text { Developing and publishing standard reports of institutional information and } \\
\text { responding to external surveys/questionnaires; Being proactive in providing } \\
\text { planning and analytical support for decision-making. }\end{array}$ \\
\hline $\begin{array}{l}\text { University of } \\
\text { South Carolina }\end{array}$ & $\begin{array}{l}\text { The OIR strives to make procedures and reports consistent, and yet also be } \\
\text { responsive to changing internal and external demands. Furthermore, the } \\
\text { Office and the University are both fundamentally committed to a high degree } \\
\text { of integration among planning, assessment, and institutional research in } \\
\text { order for the University to maintain excellence in teaching, research, and } \\
\text { public service. }\end{array}$ \\
\hline $\begin{array}{l}\text { Harvard } \\
\text { University }\end{array}$ & $\begin{array}{l}\text { To collect, synthesize, and analyze institutional data to fulfill mandatory } \\
\text { reporting requirements and support University decision-making. }\end{array}$ \\
\hline $\begin{array}{l}\text { University of } \\
\text { Kentucky }\end{array}$ & $\begin{array}{l}\text { 1. Teams compile and disseminate official university statistics on } \\
\text { enrollments, degrees conferred, and retention and graduation rates, as } \\
\text { reported in the annual UK Fact Book. } \\
\text { 2. The IR/AA staff members also deploy and analyze student and alumni } \\
\text { surveys and conduct ad hoc studies to assess institutional effectiveness. } \\
\text { 3.They help decision makers by creating data visualizations and dashboards } \\
\text { to monitor progress toward university goals } \\
\text { 4. The IR/AA office oversees data quality and releases certified institutional } \\
\text { data to external stakeholders including government agencies, accrediting } \\
\text { bodies, educational data services, corporate foundations, and members of the } \\
\text { press. }\end{array}$ \\
\hline $\begin{array}{l}\text { Office of } \\
\text { Institutional } \\
\text { Research and }\end{array}$ & $\begin{array}{l}\text { Fostering informed decision making, data literacy and institutional } \\
\text { assessment. }\end{array}$ \\
\hline
\end{tabular}




\begin{tabular}{|c|c|}
\hline $\begin{array}{l}\text { Assessment, } \\
\text { American } \\
\text { University }\end{array}$ & \\
\hline $\begin{array}{l}\text { University of } \\
\text { Pittsburgh }\end{array}$ & $\begin{array}{l}\text { 1-The Office of Institutional Research reports to the Controller within the } \\
\text { Office of the Chief Financial Officer. The Office of Institutional Research } \\
\text { (IR) produces various types of management information and provides } \\
\text { reporting services at the University of Pittsburgh including: } \\
\text { 2- Preparing University information from various databases including the } \\
\text { student enrollment history, the employee census history, and the faculty } \\
\text { activity reporting system. } \\
\text { 3- Compiling reporting requirements for the U.S. Department of Education } \\
\text { and the Commonwealth of Pennsylvania } \\
\text { 4- Providing assistance in the administration of various surveys and regularly } \\
\text { administering the Senior and CIRP surveys. }\end{array}$ \\
\hline $\begin{array}{l}\text { Office of } \\
\text { Institutional } \\
\text { Research, Yale } \\
\text { University }\end{array}$ & $\begin{array}{l}\text { 1-The Office of Institutional Information and Research (OII) serves as the } \\
\text { official data collection and reporting body for institutional information at } \\
\text { Illinois Institute of Technology. } \\
\text { 2- Reporting to the Vice Provost of Academic Affairs, OII meets federal and } \\
\text { state reporting obligations, responds to external requests for institutional } \\
\text { data, supports university business and academic units with internal reporting, } \\
\text { and maintains data standards in secure and transparent reporting } \\
\text { environment. }\end{array}$ \\
\hline $\begin{array}{l}\text { Office of } \\
\text { Institutional } \\
\text { Research and } \\
\text { Program } \\
\text { Evaluation, } \\
\text { New York } \\
\text { university }\end{array}$ & $\begin{array}{l}\text { 1-U's Office of Institutional Research is the University's central data } \\
\text { resource whose mission is to guide the University's administrative and } \\
\text { operational units for effective University growth and planning through } \\
\text { analysis, information dissemination, decision support, and technical data } \\
\text { expertise. } \\
\text { 2- The IR Team specializes in a range of areas: } \\
\text { Survey Design, Administration and Analysis } \\
\text { Retention Studies, Statistics and Predictive Modeling } \\
\text { Faculty Studies } \\
\text { Quantitative and Qualitative Data Analyses }\end{array}$ \\
\hline
\end{tabular}




\begin{tabular}{|c|c|}
\hline $\begin{array}{l}\text { Office of } \\
\text { Institutional } \\
\text { Research, } \\
\text { Wellesley } \\
\text { College }\end{array}$ & $\begin{array}{l}\text { 1- Our office informs decision-making through analytics. } \\
\text { The Office of Institutional Research, Planning and Assessment strive to } \\
\text { provide the College's academic and administrative leadership with data and } \\
\text { analysis to inform institutional planning and decision-making. } \\
\text { We serve as the primary liaison to external organizations and accrediting } \\
\text { agencies, and coordinate Wellesley's assessment efforts. } \\
\text { 2- The Office of Institutional Research is engaged in conducting research on } \\
\text { topics of interest to campus administrators or to higher education in general, } \\
\text { publishing reports to disseminate our findings, and making conference } \\
\text { presentations to build collegial relationship within the IR community. }\end{array}$ \\
\hline $\begin{array}{l}\text { Massachusetts } \\
\text { Institute of } \\
\text { Technology }\end{array}$ & $\begin{array}{l}\text { 1-The Office of Institutional Research (OIR) provides information and } \\
\text { analysis to support the decision-making process, } \\
\text { complies with reporting requirements of external agencies, and responds to } \\
\text { ad hoc requests for information } \\
\text { 2-Supports campus strategic planning and unit planning process } \\
\text { 3- Strategic Planning Data Tables. Tables developed to support strategic } \\
\text { planning for programs, departments, schools and colleges. This information } \\
\text { is provided for general use, and also to help units respond to the questions } \\
\text { posed in Phase III unit planning. } \\
\text { 4- Organizational Chart. A visual representation of the structure of the } \\
\text { organization and relationship between those units. } \\
\text { 5- Performance Measurement System Annual Indicators Report. 6-Produced } \\
\text { annually for UMass President's Office in collaboration with other UMass } \\
\text { campuses. Compares the University of Massachusetts Amherst with peer } \\
\text { institutions in many areas, including academic quality, access and } \\
\text { affordability, student success and satisfaction ,service to the Commonwealth, } \\
\text { and financial health. }\end{array}$ \\
\hline
\end{tabular}

\section{Methodology}

This study would be intended to provide new solutions for the academic organizational development. Qualitative method has been used in this study. By comparative studies, this study made a comparison analysis of IR dimensions of selected universities. Strategic elements of IR have been extracted from this comparison.

\section{Research Findings}

\subsection{Analysis of contents of texts and documents}

Through investigating and analyzing the articles contents on the IR features (categorized in 


\section{Macrothink}

International Journal of Human Resource Studies

ISSN 2162-3058

2016, Vol. 6, No. 2

Table.1) as well as the OIR functions in the selected universities(categorized in Table.2), 1 main category, 3 secondary categories, and 21 subcategories were identified and presented in the table 3:

Table 3. Categorizing IR features with regard to the common cases

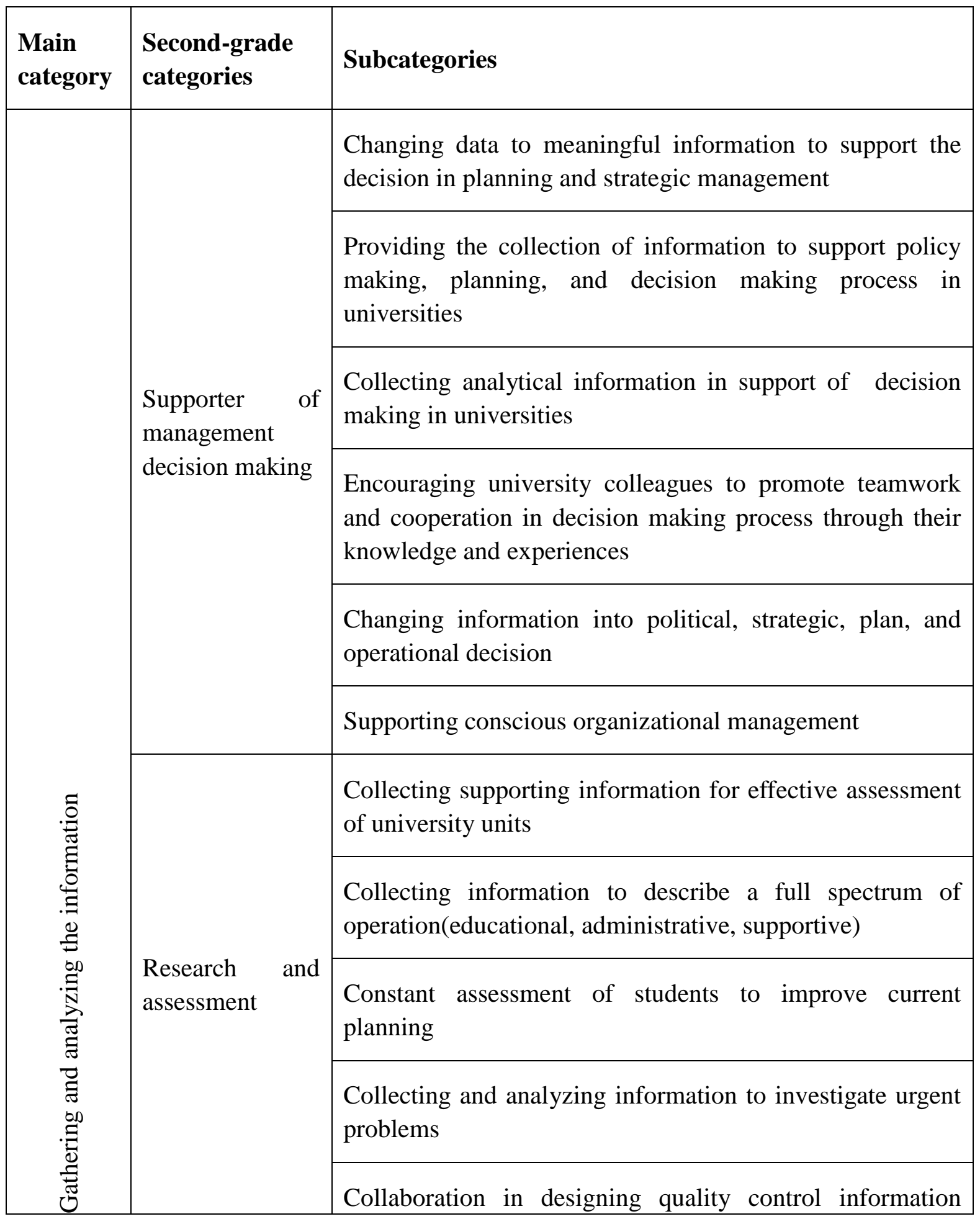




\begin{tabular}{|c|c|}
\hline & system and applying this system \\
\hline & $\begin{array}{l}\text { Research and assessment of process, plans, performance, } \\
\text { resources, efficiency, and effectiveness }\end{array}$ \\
\hline \multirow{9}{*}{$\begin{array}{l}\text { Particular } \\
\text { interaction with } \\
\text { environment }\end{array}$} & Linking data to the internal and external fields of university \\
\hline & Reviewing students' curriculum to meet external demands \\
\hline & $\begin{array}{l}\text { Having field intelligence, that is, sufficient knowledge of } \\
\text { cultures and values across the university borders }\end{array}$ \\
\hline & A factor linking university to industry \\
\hline & Systematic response \\
\hline & $\begin{array}{l}\text { Presenting reports about the needs of state and federal } \\
\text { organizations }\end{array}$ \\
\hline & Studying and analyzing the environment \\
\hline & Identifying new opportunities \\
\hline & Studying the process of higher education policies \\
\hline
\end{tabular}

\section{Conclusion}

Regarding the findings of the research, it was concluded that collection, analysis, and publication of information was considered as the main category and "studying process, plans, performance, resources, and effectiveness of decision maker units", "supporting IR decision making in planning and policy making", and "particular interaction with environment" were regarded as three subcategories. The mentioned categories will have strategic role in organizational development, since university organizational development is based on its effect on situations and environmental requirements which involves research and assessment of university unit performance and decision making based on necessary measures for stable development of universities. Therefore, it can be concluded that IR is a systematic complex for organizational development of universities.

Based on the findings of Table 1 and 2, it is inferred that; Institutional research is a process consisting of collecting and analyzing internal and environmental information and changing them to operational, planned, strategic, and political decisions to support university managers' decision making for planning and policy making. We have shown the system of IR in figure 1 and the conceptual framework in figure 2. 
Figure 1. The system of IR

\begin{tabular}{|l|l|l|} 
Input: \\
1. Information \\
inside the \\
universities \\
(internal \\
information) \\
2. Environmental \\
information
\end{tabular}

Figure 2. IR conceptual framework

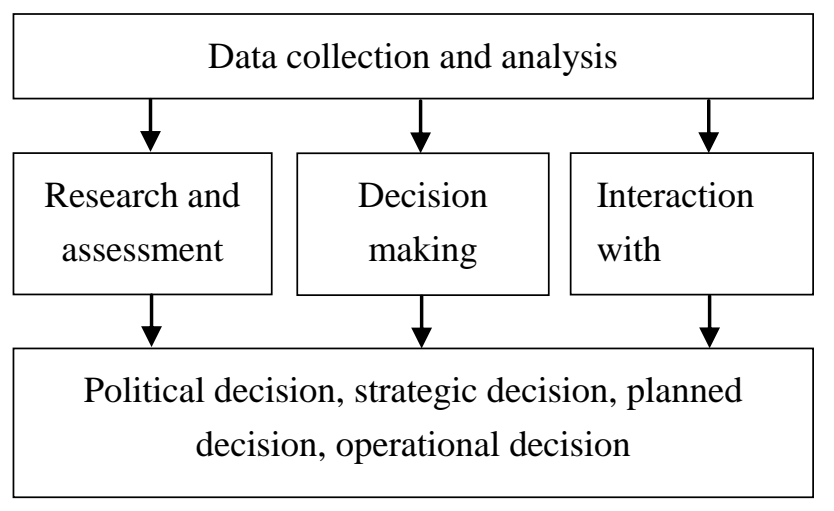

The presented study identified four main IR dimensions whose qualities have determining role in organizational development in each university. These four dimensions were as follow: operational decisions, planned decisions, strategic decisions, and political decisions. Moreover, key decision making factors, namely research and assessment, decision making, and particular interactions with environment, can be used as a new approach in academic management. Orientation of university organizational development focused on improvement of traditional and participatory decision making, since changing and developmental process in higher education depicts changes resulted from increase in number of students, increase and variety of education organizations, internationalization of higher education, rapid change in technology, changing stakeholders' expectation and financial pressure. Thus, academic management and decision making are considered to be very complicated. In such situation, a review on OIR goals and strategies is an inevitable necessity.

\section{References}

Brenda .H. Rogers, 1989, The value of Institutional Of Research in the Assessment of Institutional Effectiveness Research in Higher Education, Vol. 30, No. 3,

Coughlin, Mary Ann, Joseph Hoey, Marsha Hirano-Nakanishi , 2009, Sector differences 


\section{Macrothink}

International Journal of Human Resource Studies

ISSN 2162-3058

2016, Vol. 6, No. 2

in the role of institutional research in informing decision making and governance in higher education Asia Pacific Educ. Rev.10:69-81

Entezari, Yahgoob, 2006, "Institutional Research for knowledge Development Productivity in Iran University", Higher Education Letter, Vol.1-4 (in Persian).

Knight, William E., 2010, "In Their Own Wordes: Effectiveness in Institutional Research" Association for Institutional Research.No.115.

Olsen, Deborah, 2000, "Institutional Research", New Directions for IR, N.111, P.103-111, Jossey-Bass, a Wiley Company.

Rangriz H, Khorshidi GH. Management information system, 2008, Tehran: Bazargani Publishing. p. 84.

Saupe, Joe L, \& James R. Montgomery, 1970, The Nature and Role of Institutional Research, Memo to a college or University, Berkeley, California: Association for Institutional Research.

SarrafiZadeh A, Ali .panahi A., 2003, Management Information Systems, Theories, Concepts and Applications. Tehran: Mir Publishing, p. 3.

Saketi, Parviz, 2007, Institutional Research Introduction, Research and Planning in Higher Education, 52nd University Presidents and Scientific Centers Managers Summit, Research and Technology.

Terenzini , Patrik ,2013, "On the Nature of Institutional Research and Knowledge and Skills it Requires", New Directions for IR,No.104,p.21-29,US: jossey-Bass publishers.

Taylor, A. L., 1979, Decision process behaviors of academic managers. The Association for Institutional Research, San Diego, California.

Volkwein, J. Fredericks, 2008 , The Foundations and Evolution of Institutional Research, N.141, P.5-20.

Voorhees .Richard .A. 2008, Institutional Research's Role in Strategic Planning NEW DIRECTIONS FOR HIGHER EDUCATION, no. 141.

Webber .Karen L., 2012, The Role of Institutional Research in a High Profile Study of Undergraduate Research, 53:695-716.

Anselm L. Strauss, Juliet M. Corbin, 1990, Basics of qualitative research: grounded theory procedures and techniques, Sage Publications, - Social Science - 270 pages.

Javdani H., 2012, Policy research, Tehran University, page 16-37.

Farastkhah Maghsood, 2008, University and Higher education from universal view, Tehran University. 


\section{Macrothink}

International Journal of Human Resource Studies

ISSN 2162-3058

\section{Copyright Disclaimer}

Copyright for this article is retained by the author(s), with first publication rights granted to the journal.

This is an open-access article distributed under the terms and conditions of the Creative Commons Attribution license (http://creativecommons.org/licenses/by/3.0/). 